\title{
The genus Colura (Lejeuneaceae, Marchantiophyta), new to Singapore
}

\author{
J. Sangrattanaprasert ${ }^{1}$, B.C. Ho $^{2}$, S. Chantanaorrapint ${ }^{1} \&$ R.-L. Zhu ${ }^{3}$ \\ ${ }^{1}$ Department of Biology, Faculty of Science, Prince of Songkla University, \\ Hat Yai, Songkhla 90112, Thailand \\ sahut.c@psu.ac.th \\ ${ }^{2}$ Singapore Botanic Gardens, National Parks Board, \\ 1 Cluny Road, 259569, Singapore \\ ${ }^{3}$ Department of Biology, School of Life Sciences, East China Normal University, \\ 3663 Zhong Shan Road, Shanghai 200062, China
}

\begin{abstract}
Colura brevistyla Herzog is reported here as a new genus and species record for Singapore. A complete description and illustrations of $C$. brevistyla are provided based on the newly identified specimen from Singapore.
\end{abstract}

Keywords. Colura, Colura pluridentata, Frullania nodulosa, leafy liverwort, Malesian region, mangrove forest

\section{Introduction}

The genus Colura (Dumort.) Dumort. was first described as a section of Jungermannia L. (Dumortier, 1831) and was subsequently raised to generic rank by Dumortier (1835) based on C. calyptrifolia (Hook.) Dumort. It is one of the larger genera of the Lejeuneaceae and is divided into two subgenera and six sections with about 83 currently accepted species (Grolle \& Zhu, 2002; Söderström et al., 2016). Colura can be recognised mainly by the following set of morphological features: 1) underleaf deeply bilobed, one per lateral leaf; 2) leaf lobules tubular to cylindrical, usually broadening distally and terminating in a sac; 3 ) lobule sac with a valve and a pore. The genus is distributed mainly in tropical and subtropical regions (Zhu \& So, 2001; Frey \& Stech, 2009), with a hotspot in the Malesian region (Pócs, 1996).

Colura has been widely recorded from many of Singapore's neighbouring countries, e.g. Cambodia, China, India, Indonesia, Malaysia, Philippines, Papua New Guinea, Sri Lanka, Thailand, and Vietnam (Jovet-Ast, 1953; Zhu \& So, 2001, Lai et al., 2008; Pócs \& Lee, 2016; Sangrattanaprasert et al., 2017), but has not previously been reported for Singapore (Piippo et al., 2002; Zhu et al., 2018). This is probably due to their diminutive size with highly reduced morphological structures, which results in them being easily overlooked in the field. During re-examination of existing herbarium specimens for the Flora of Singapore, an interesting collection of the genus Colura was discovered on another leafy liverwort: Frullania nodulosa (Reinw., Blume $\&$ Nees) Nees. The material was segregated and made into a separate specimen with an added suffix ' $b$ ' to the collection number. Based on relevant literature and comparison with type specimen, it was identified as Colura brevistyla Herzog, a new species and genus record for the country. The description and illustrations below are based on the cited Singaporean specimen. 


\section{New species record for Singapore}

Colura brevistyla Herzog, Bot. Centralbl. Beih. 38(2): 331 (1921); Jovet-Ast, Rev. Bryol. Lichénol. 22: 276 (1953). - TYPE: Sri Lanka (Ceylon), 1906, T. Herzog s.n. (holotype JE [JE04005002]). (Fig. 1)

Plants $0.5-1 \mathrm{~cm}$ long; shoots c. $2.5 \mathrm{~mm}$ wide; irregularly pinnately branched, branches of Lejeunea-type. Stem 70-100 $\mu \mathrm{m}$ in diameter, in transverse section consisting of 7 cortical cells $(30-54 \times 20-40 \mu \mathrm{m})$ and 3 medullary cells $(30-40 \times 20-24 \mu \mathrm{m})$; ventral merophyte of stem 2 cells wide. Rhizoids numerous, fasciculate at base of underleaves. Leaves contiguous to imbricate, spreading from stem at an angle of $45^{\circ}-90^{\circ}$. Lobes 1-1.4 mm long, 0.28-0.56 mm wide; dorsal margin flattened, crenulate or almost entire in immature plant. Lobe cells thin-walled, trigones large, intermediate thickenings distinct; marginal cells subquadrate to rectangular, 20-30 $\times 20-30 \mu \mathrm{m}$; median cells rectangular, 50-60 × 18-26 $\mu \mathrm{m}$; basal cells rectangular, 40-66 $\times 20-26 \mu \mathrm{m}$. Oil bodies not seen. Lobules narrowly tubular, flaring toward sac, 1.6-2.1 mm long. Lobule sac cylindrical fusiform to lanceolate, strongly inflated, $0.64-0.8 \mathrm{~mm}$ long, $0.18-0.26$ mm wide, apex obtuse, entire; sac surface mammillose. Valves complex-type, ovate to elliptic, $80-100 \times 76-80 \mu \mathrm{m}$, composed of one circle of 18-21 hyaline marginal and 18-29 median cells with 1-2 basal median cells, hinge of 3 cells. Hyaline papilla bulbous to spherical, 16-20 $\mu \mathrm{m}$ in diameter. Valve frame outline semicircular with triseriate cells, 90-120 $\mu \mathrm{m}$ wide; cell walls entire. Underleaves distant, deeply bilobed, sinus acute; lobe triangular to lanceolate, 320-480 × 80-160 $\mu \mathrm{m}, 14-18$ cells long, 7-9 cells wide at base; margin entire. Androecium and Gynoecium not seen. Asexual reproduction by discoid gemmae, occurring on apex of lobule sac.

Distribution. Fiji (Viti Levu and Taveuni), Malaysia (Peninsula), Mariana Island, Philippines, Sri Lanka, Thailand, Vietnam (Pócs et al., 2011; Pócs \& Lee, 2016; Shu et al., 2017), new to Singapore.

Habitat and ecology. In Singapore, Colura brevistyla was found growing on Frullania nodulosa in Sungei Buloh, a mangrove forest gazetted as a Nature Reserve and officially named Sungei Buloh Wetland Reserve in 2002.

Specimen examined. SINGAPORE: Sungei Buloh, 30 Nov 1889, Goodenough 1207b (SING [SING0017075]).

Taxonomic notes. The distinctive features of Colura brevistyla are: 1) lobules inflated forming a narrow cylindrical to lanceolate sac with obtuse or truncate apex; 2) leaf dorsal margin entire to crenulate; and 3) underleaf lobes large at 14-18 cells long and 7-9 cells wide at base. Moreover, leaves of this species are usually erect and often produce gemmae on their protruded leaf apices. Based on our examination of the type material and some additional collections of Colura brevistyla, we found that some very old collections were difficult to rehydrate completely and bear involute leaf lobes. This feature differs somewhat from the original illustration by Herzog (1921) and the more recently published photos of fresh materials (Pócs et al., 2011; Pócs \& Lee, 2016).

Colura brevistyla is morphologically similar to $C$. pluridentata Jovet-Ast. These two species share the characters of underleaf form, shape of lobule sac, valve 


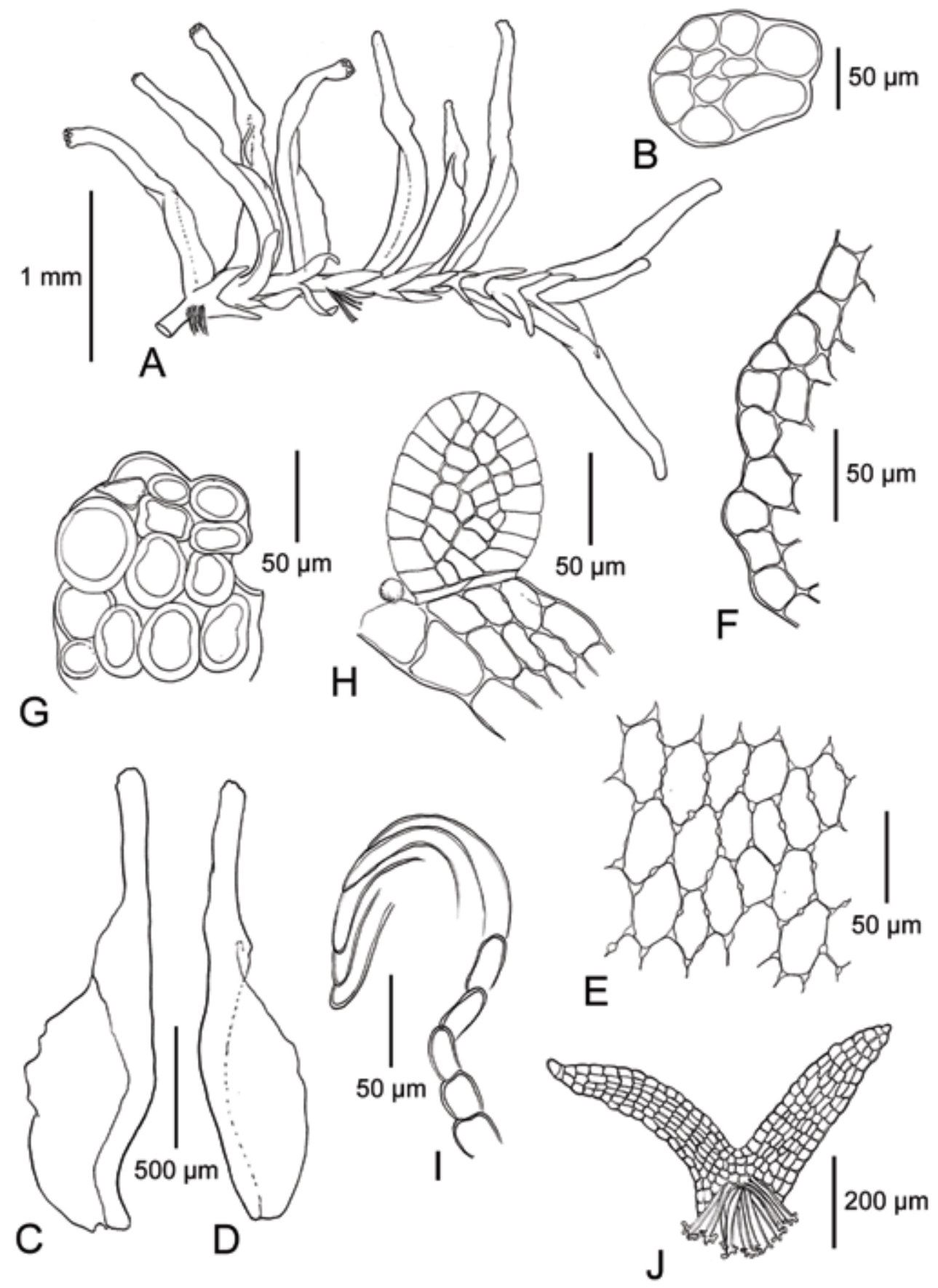

Fig. 1. Colura brevistyla Herzog: A. Portion of plant, side view. B. Stem in transverse section. C. Lateral leaves, ventral view, D. Lateral leaves, dorsal view. E. Leaf lobe median cells. F. Leaf lobe marginal cells. G. Lobule sac apex with remain cells developing gemmae. H. Valve. I. Valve frame. J. Underleaf. All from Goodenough 1207b (SING). (Drawn by: J. Sangrattanaprasert) 
type, etc. Colura pluridentata differs primarily in the strong teeth on the dorsal margin of the leaf lobe and the number of basal median cells of the valve (Jovet-Ast, 1953). However, based on an investigation on a wider range of specimens of Colura pluridentata, the species is rather variable in the lobule sac length, the teeth on the dorsal margin of leaf, and the number of basal median cells of the valve (unpublished data). Thus, these two species may possibly be conspecific; molecular phylogenetic studies could help to clarify this. If this synonymy is confirmed, Colura brevistyla would have nomenclatural priority.

ACKNOWLEDGEMENTS. The authors would like to thank the curators and staff of BCU, BO, EGR, HSNU, JE, L, MO, and SING for making specimens, including types, available for study through loans and visits. This research was financially supported by Graduate School, Prince of Songkla University, and by the National Natural Science Foundation of China (nos. 31570206 \& 31770224). Finally, funding by the Science Achievement Scholarship of Thailand (SAST) is gratefully acknowledged by the first author.

\section{References}

Dumortier, B.C.J. (1831). Sylloge Jungermannidearum Europae Indigenerum. Tornaci Nerviorum: J. Casterman.

Dumortier, B.C.J. (1835). Recueil d'observation sur les Jungermanniacées, Fascicule I. Révision des Genres. Tournay: Imprimerie De J.-A. Blanquart.

Frey, W. \& Stech, M. (2009). Marchantiophyta, Bryophyta, Anthocerotophyta. In: Frey, W. (ed.) Syllabus of Plant Families. Adolf Engler's Syllabus der Pflanzenfamilien, $13^{\text {th }} \mathrm{ed}$., Part 3. Bryophytes and seedless Vascular Plants, pp. 9-263. Stuttgart: Gebr. Borntraeger Verlagsbuchhandlung.

Grolle, R. \& Zhu, R.-L. (2002). On Macrocolura and the subdivision of Colura (Lejeuneaceae, Hepaticae). J. Hattori Bot. Lab. 92: 181-190.

Herzog, T. (1921). Die Lebermoose der 2. Freiburger Molukkenexpedition und einige neue Arten der engeren Indomalaya. Bot. Centralbl. Beih. 38: 318-332.

Jovet-Ast, S. (1953). Le genre Colura, Hépatiques, Lejeuneacées, Diplasiae. Rev. Bryol. Lichénol. 22: 206-312.

Lai, M.-J., Zhu, R.-L. \& Chantanaorrapint, S. (2008). Liverworts and hornworts of Thailand: and updated checklist and bryofloristic accounts. Ann. Bot. Fenn. 45: 321-341.

Piippo, S., He, X.-L., Juslén, A., Tan, B.C., Murphy, D.H. \& Pócs, T. (2002). Hepatic and hornwort flora of Singapore. Ann. Bot. Fenn. 39: 101-127.

Pócs, T. (1996). Epiphyllous liverwort diversity at worldwide level and its threat and conservation. Anales Inst. Biol. Univ. Nac. Autón. México, Bot. 67: 109-127.

Pócs, T., Sass-Gyarmati, A., Naikatini, A., Tuiwawa, M., Braggins, J., Pócs, S. \& von Konrat, M. (2011). New liverwort (Marchantiophyta) records for the Fiji Islands. Telopea 13: 455-494.

Pócs, T. \& Lee, G.E. (2016). Data to the Malaysian Liverwort Flora, II. Cryptog. Bryol. 37(1): $39-52$.

Sangrattanaprasert, J., Chantanaorrapint, S. \& Zhu, R.-L. (2017). Notes on Colura crenulata (Lejeuneaceae, Marchantiophyta), a new record for Thailand, with a sporophyte description. Polish Bot. J. 62(2): 197-202.

Shu, L., Xiang, Y.-L., Cheng, X.-F., Wei, Y.-M., Wang, J., Zhang, L.-N., Li, W., Yin, X.-B., Zhang, W.-P., Zhao, C.-X., Peng, T., Do, T.V., Lu, T.N. \& Zhu, R.-L. (2017). New liverwort and hornwort records for Vietnam. Cryptog. Bryol. 38(4): 411-445. 
Söderström, L., Hagborg, A., von Konrat, M., Bartholomew-Began, S., Bell, D., Briscoe, L., Brown, E., Cargill, D.C., Costa, D.P., Crandall-Stotler, B.J., Cooper et al. (2016). World checklist of hornworts and liverworts. PhytoKeys 59: 1-828.

Zhu, R.-L. \& So, M.-L. (2001). Epiphyllous Liverworts of China. Beih. Nova Hedwigia 121: $1-418$.

Zhu, R.-L., Lu, C.-H. \& Shu, L. (2018). Additions and corrections for liverworts and hornworts of Singapore. Philipp. J. Syst. Biol. 12: 12-21. 